\title{
Freedom of will and its limitations: comparative study of legal norms in Russia and the USA
}

\author{
Vera Borshcheniuk $^{1}$, Nina Semerianova ${ }^{1 *}$, Uliana Filatova $^{2}$, Oleg Karpovich ${ }^{3}$ \\ ${ }^{1}$ South Ural State University (National Research University), 628600, 9, Mira str., Nizhnevartovsk \\ Branch, Russia \\ ${ }^{2}$ Irkutsk State University, Law Institute, 664082, 10, Ulan-Batorskaya str., Irkutsk, Russia \\ ${ }^{3}$ Diplomatic Academy of Ministry of Foreign Affairs of the Russian Federation, 119021, 53/2, \\ Ostozhenka str., Moscow, Russia
}

\begin{abstract}
The relevance of the study is determined by the dynamics of development of inheritance law, both in general and its individual institutions, in particular, the institution of inheritance by will. Due to changes in Russian legislation, it is advisable to conduct a comparative legal analysis of the provisions on free will and the limits of its restriction to Russia and the United States. This will make it possible to determine the potential of the institution under study, used by various legal systems, to indicate direction of its further development in Russia. The leading research approach includes such scientific methods as dialectics, analysis, synthesis, deduction, comparative legal and formal legal method. Conclusions: The scientific approaches to understanding and restraining free will provided by US law differ significantly from their understanding by Russian law, which belongs to the Romano-German legal family. The right to choose the option of accepting the inheritance and the rules on the mandatory share, enshrined in Russian law, testify to the development of inheritance law towards a balance of interests of participants in inheritance relations by establishing new limits for implementation of the testator's will.
\end{abstract}

\section{Introduction}

Inheritance law of Russia and the USA, despite significant differences in legal systems, proceeds from two fundamental principles - freedom of will and protection of the interests of the family. These principles play an important role in the law of any state.

In legal science, freedom of will is understood as the inalienable right of any citizen to designate a list of persons who, according to his will, will receive property after the death of the testator. However, this freedom is not unlimited. The law protects a particular category of the population from depriving them of a portion of their estate. These rules limit the freedom of wills.

The principles of US inheritance law are contained in the Constitution, federal regulations, state regulations, case law acts. US law of succession has its own

*Corresponding author: a.copytowa@yandex.ru 
characteristics. These features are possible due to the presence of three systems of law in one country - General, European (in Louisiana) and ordinary Native American. Describing US law, a number of Russian authors speak of it as a tangled ball consisting of English General Law and Justice Law, state case law and federal precedents, uniform state laws and regulations, prevailing legal doctrines and "minority rules", judicial discretion and acts of doctrinal interpretation of law, opinions of authoritative jurists and annotations to laws, rules of interpretation based on the intended intention and numerous exceptions to the exceptions [1]. In order to systematize numerous sources of inheritance law, an attempt was made to unify acts regulating inheritance relations. The result of this work was the adoption of the Uniform Probate Code, recognized by individual states as part of its legal system, and regulating the freedom of will and cases of its restriction.

In Russia, according to Part 4 of Art. 35 of the Constitution of the Russian Federation, the right to inherit is guaranteed. This right includes both the right of the testator to dispose of his property, and the right of the heirs to receive it (part 2 of article 35 of the Constitution of the Russian Federation). This provision of the Constitution of the Russian Federation discloses the principle of freedom of inheritance, including the principle of freedom of will, which is directly enshrined in Art. 1119 of the Civil Code of the Russian Federation. The freedom granted to a citizen by order of his property in case of death may be limited by the only rule established by law on the mandatory share of inheritance (Article 1149 of the Civil Code).

The institution of a mandatory share in the law of succession is known to almost any legal system. The evolution of inheritance law began in ancient times, when the testator enjoyed unlimited freedom and could bequeath his property to completely random people. Over time, in Roman law, the provision on the mandatory share of the testator's children was enshrined, limiting the freedom of testamentary disposition, the circle of mandatory heirs was expanded, the size of the mandatory share changed repeatedly (E.A. Kirillova, Yu.A. Lukash, Z. Krylova). Radical proposals have also been made, such as the complete abolition of the right of inheritance or its restriction through the introduction of an inheritance tax (A. Saint-Simon, S.-A. Bazar). These proposals of the socialists had a significant impact on the founders of Marxism. K. Marx and F. Engels in the Manifesto of the Communist Party indicated as one of the most important revolutionary events - the abolition of the right to inherit. An attempt to implement this policy statement was made by the Decree of the All-Russian Central Executive Committee of April 18, 1918 "On the abolition of inheritance." However, soon the Decree of the All-Russian Central Executive Committee of May 22, 1922 "On Basic Private Property Rights Recognized by the RSFSR, Protected by its Laws and Protected by the Courts of the RSFSR" revived the right of inheritance, albeit in a very limited form. With the adoption of part three of the Civil Code of the Russian Federation and the abolition of the tax on property transferred in the order of succession, the law of succession returned to its normal state. At present, both states (Russia and the USA) consider the interests of the testator not only as a family-securing function of inheritance, but also as an opportunity to transfer property to other persons capable of managing the testator's bequeathed property.

Theoretical basis of the study was formed by the scientific works of Russian and foreign authors, such as M.M. Agarkov, S.S. Alekseev, M.Yu. Barshchevsky, G.J. Berman, O.Yu. Borovik, E. Jenks, S. Jnson, R.F. Zakharova, O.S. Joffe, H. Koch, L.A. Lunts, E. Mellows, L.Yu. Mikheeva, R.L. Naryshkina, V.B. Panichkin, V.I. Serebrovsky, E.A. Sukhanov, R. Walker, E.A. Fleishits, K.V. Khramtsov and many others who addressed the general issues of inheritance, the hereditary process and the institution of trust. Empirical basis of the work is formed by the legislation of Russia and the USA, as well as a number of judicial precedents (Estates of Alex (Boney) Dixon \& Kenneth A. Dixon. IA-1148 (April 28, 1961); 
Byars v. Mixon, 299 So. 2d 262 ( Ala. 1964); Jazo v. Jazo, 129 NW 2d 195 (Wis. 1964) and others)

Methodological basis of the study includes basic theoretical provisions of the science of general theory of law, civil law and civilistic doctrine of the will and its restriction. When conducting the research, historical, dialectic, comparative legal and formal legal methods were used. General logical methods were also used - analysis, synthesis, deduction, induction, abstraction, generalization.

The purpose of the study is to scientifically comprehend the provisions on free will and its limitations, in assessing the role of these restrictions in modern civil circulation. To achieve this goal, the following research tasks are formulated: to reveal the nature of relations that limit the will of a will; to summarize the legal regulations of the two states in this area; to analyze the current regulatory framework and acts of interpretation of law in the field of restriction of the will of will; to identify the main trends in the development of Russian law in the field of limitation of wills.

The scientific novelty of the study lies in the author's approach to the issue of accepting an inheritance from the standpoint of the dispositiveness of the norms of Russian inheritance law, which is expressed in the freedom of the will and mutually exclusive rights to accept or refuse the inheritance, as well as in the right to choose the option of accepting the inheritance.

\section{Discussion}

In the Russian legal literature, various opinions are expressed regarding the content of the concept of an obligatory share in the inheritance. So, the mandatory share is understood as "a part of the inheritance property that must be transferred to the heir regardless of what the will says" [2], as "a certain share in the inheritance that is reserved for a special category of heirs regardless of the contents of the will" [3], as "personal provision" [4] and as "a kind of guarantee minimum for the necessary heirs."

Debatable remains the question of the legal nature of the limitation of the will. We agree with the position of A.V. Lebedeva, in whose opinion, the provision on the mandatory share limits not the freedom of the will of the testator, but the realization of the will expressed in the will. Since a will is an expression of a person's last will, and since a person is always a goal-setting creature that sets goals for himself, reflecting his ideas about his due, about his ideal state, it is in the ability of goal-setting that the will and its independence are manifested. As noted by V.I. Polishchuk, an addicted person, is not able to set a goal for himself, because he is fulfilling someone else's goal or the will of another person imposed on him. Goal-setting is the meaning-forming content of practice, consisting in the formation of the goal as a subjectively ideal image of the desired (goal-formation) and its embodiment in the objectively real result of activity (goal-realization). However, goal setting and goal realization may not always coincide. Here we can draw an analogy with voting in a jointstock company, where voting is an act of realizing the will of a shareholder. The shareholder's will expressed by voting may be in the minority and remain, although expressed, but not realized. It is the same with a will in which the testator freely expresses his will, but this does not guarantee its full realization. Therefore, in this case, it is not freedom of expression of the will of the testator that is limited, but the possibility of its realization, that is, the goal set by the testator may not be achieved, or it may be achieved but not to the extent that he intended. This is an example of a legal compromise, "legal humility," since the goals set by the testator confront the rights of others who are enshrined in law and their existence does not depend on the will of the testator.

In addition, the Constitutional Court of the Russian Federation in determination No. 209-O of December 9, 1999 indicated that the presence of the heir of a right to an 
obligatory share in the inheritance does not exclude the right of other heirs to apply to the court with a claim to verify the grounds for recognizing the right of this person to be obligatory share in the inheritance and the change in its size, taking into account the actual circumstances of a particular case [5].

Many authors reacted negatively to the clarifications of the Constitutional Court, and expressed their doubts about the advisability of referring these issues to the discretion of the court (I.Yu. Voronov, Yu.S. Kharitonova, L.I. Popova). Other authors note that it is not necessary to absolutize the right of the necessary heirs to an obligatory share, especially in those cases when they do not have a special interest in obtaining the corresponding property, the person's disability does not necessarily automatically entail his financial insecurity (M.L. Kovaleva, N.V. Shcherbina).

Unlike the Roman-Germanic system of law, which provides for an obligatory share in the inheritance, most American states for a long time provided family members with only family allowance to support them for the period of distribution of inheritance property. Currently, all states protect spouses and children from dispossession. But spouse rights are more protected in American law than children's rights. It is believed that even if the spouse does not need material support, he has a moral right to demand that a share of the property be allocated to him, since both spouses participate in the formation of property during marriage, and do it much more actively than children [6].

\section{Results}

According to the Common Law applied by most US states, a surviving spouse is not recognized as an heir, such as, for example, by Russian law. In Russia, the surviving spouse has the right to $1 / 2$ share in the inheritance, unless a different size of the share was determined by a marriage contract, joint will of the spouses, a hereditary contract or a court decision (Article 256 of the Civil Code of the Russian Federation, Article 34 of the IC of the Russian Federation), i.e. included in the hereditary mass. Under US inheritance law, in the absence of heirs (descendants, parents, blood relatives), the property of the testator is recognized as being extinct. The surviving spouse has the only right - the right to upkeep. Such a right was recognized as "frozen," it entered into force only after the death of one of the spouses. However, the spouse, unlike the wife, received this right only on condition that a child was born in the marriage. Thus, the freedom of the will of each spouse by US law is limited by the right of the other to receive maintenance. Moreover, this right is not affected by the transfer of ownership of real estate to other persons, including during lifetime transfer (lifetime conveyance), as well as when transferring real estate to a bona fide purchaser, if the surviving spouse does not give consent to the transaction.

US law secures the surviving spouse's choice of elective share statutes. This means that the surviving spouse has the right to choose to act in his own interest - to inherit by will, or to receive an obligatory share (as a rule, this is $1 / 2$ or $1 / 3$ part), or to receive maintenance. The possibility of such a choice for the surviving spouse is subject to the condition of having a marriage. Also, the right is given to choose the mandatory share on behalf of the incompetent or minor spouse to their guardian or trustee, if this choice is made in the interests of the surviving spouse. However, property received as a mandatory share is transferred not to property, but to a trust for the entire period of the surviving spouse's life, and after his death returns to the property of the first testator ( $\$ 2-2012$ (b) of the ESC).

The legislation of New York seems interesting from the point of view of the ratio of freedom of a will, according to which, when a will providing for the transfer of certain property to the surviving spouse is less than the size of the mandatory share, the right to choose the type of inheritance is limited to accepting the property by will. In this case, the 
surviving spouse has the right to receive the difference between the value of the bequest of property and the size of the mandatory share.

According to Russian law, persons entitled to an obligatory share include the minor or disabled children of the testator, his disabled spouse and parents, as well as disabled dependents of the testator, who are subject to the call to inherit on the basis of clauses 1,2 of Art. 1148 of the Civil Code of the Russian Federation. Such persons inherit, regardless of the contents of the will, at least half of the share that would be due to each of them when inheriting by law (mandatory share).

If the exercise of the right to an obligatory share in the inheritance entails the inability to transfer to the heir by will the property that the heir who has the right to the obligatory share did not use during the life of the testator, and the heir used the will to live (apartment building, apartment, other residential premises, cottage, etc.) or used as the main source of livelihood (tools, a creative workshop, etc.), the court may, taking into account the property status of heirs entitled to a mandatory share, reduce the size of the mandatory share or refuse to award it.

An heir who has the right to an obligatory share and is the beneficiary of the inheritance fund shall lose the right to an obligatory share. If such an heir, within the time period established for the acceptance of the inheritance, notifies the notary in charge of the succession of the beneficiary of the inheritance fund, he has the right to an obligatory share [7].

Russian law knows such a category of heirs as the "unworthy heir". In accordance with Art. 1117 of the Civil Code of the Russian Federation, neither the law nor the will shall be inherited by citizens who, through their deliberate unlawful actions directed against the testator, any of his heirs, or against the implementation of the testator's last will expressed in the will, contributed to or tried to facilitate the calling of themselves or other persons to inheritance either contributed or tried to help increase the share of the inheritance due to them or other persons, if these circumstances are confirmed in court. However, citizens have the right to inherit the property if the testator bequeathed this property after they lost the right to inherit. This provision is fully consistent with the principle of free will. Parents do not inherit by the law after children if they are legally deprived of parental rights and are not reinstated in these rights by the opening day of the inheritance. Also, at the request of the person concerned, the court removes from inheritance, by law, citizens who maliciously evaded the fulfillment of the duties of keeping the testator lying on them by force of law. These rules apply to heirs who have the right to an obligatory share in the inheritance, as well as to cases of testamentary refusal, when its subject was the performance of certain work (provision of services) for an unworthy receiver [8].

According to the rules of most states, the surviving spouse is entitled to a mandatory share in the inheritance even if he abandoned his spouse, refused to support her, changed (has committed adultery) or is guilty in some other misconduct. This is because the right to an obligatory share is granted by law, and if the state legislature has not established that the surviving spouse has the right to inherit only with his good behavior towards the deceased spouse, the courts are not entitled to attach importance to such behaviour [9-11].

\section{Conclusion}

1. The right to accept or refuse an inheritance is known to any legal system. In addition to these opposed opportunities, US inheritance law is well aware of such a category as "the right to choose the option of accepting the inheritance." Such a right arises from the surviving spouse, he can inherit the property by will, accept an obligatory share, or choose the right to receive maintenance. For a particular category of persons, such as a legally incompetent or minor spouse, the right to choose does not arise. In this case, they receive 
life-long maintenance, and the estate is transferred to the trust. The right to choose the option of accepting the inheritance is new to the Russian inheritance law. It occurs when the heir becomes the beneficiary of the inheritance fund. In this case, he is granted the right to accept the mandatory share and thereby refuse the content, or maintain the status of the beneficiary, but lose the right to the mandatory share. Therefore, through the right to accept the inheritance and the right to choose the option of accepting the inheritance, the principle of freedom to accept the inheritance is implemented. Expanding the ability to choose the right by the heir sets the limits for the implementation of the testator's will, thereby the legislator ensures a balance of interests of the parties to the inheritance relationship.

2. The scientific approaches to understanding and restricting testament freedom provided for by US law are significantly different from their understanding by Russian law, which belongs to the Roman-German legal family. Most US states do not recognize the system of separate property as the common property of spouses, so the surviving spouse is not legally the heir, but has the right to a mandatory share. In Russian law, the institution of common joint property is used, according to which, half of the property acquired during the marriage is not part of the estate and is recognized as the personal property of the surviving spouse. The second part of the joint property of the common property of the spouses is distributed among the heirs under the law in order of priority in the absence of a will. The surviving spouse is the heir to the first stage, along with the children and parents of the spouse, as well as in their absence. In the USA, on the contrary, in the absence of children, parents and other blood relatives, the property of the testator is recognized as being extinct, and the surviving spouse owns only the right to support. Consequently, Russian law in relation to the surviving spouse is more loyal, which, in our opinion, is an absolute advantage of regulation. Spouse Common Assets apply only to a few US states.

3. Certain provisions of the Russian inheritance law on the mandatory share are at the discretion of the court (for example, if the heir renounces the rights of the beneficiary of the inheritance fund). In this case, the risk of receiving it in the amount other than the heir is supposed to increase significantly. Preservation of the size of the mandatory share or its reduction is made dependent on the discretion of the court. The status of the beneficiary is more guaranteed for the heir. Thus, the legislator, following the principle of free will, ensures the maximum realization of the testator's will.

4. The provision on "unworthy heirs" enshrined in Russian law, depriving them of the right to inherit for their unworthy behavior, seems more consistent with the principle of free will than the American right to a mandatory share, which does not depend on the behavior of the heirs (the exception is the killing by the heir of the testator), is more restrictive.

5. The right to choose the option of accepting the inheritance and the rules on the mandatory share testify to the development trend of the Russian inheritance law in the direction of ensuring a balance of interests of participants in the legal relations by establishing new limits for the implementation of the testator's will. Therefore, we can expect that in the future the law of succession will reach its peak as a highly developed institution of civil law.

\section{References}

1. V.B. Panichkin, O.Yu. Borovik, US Inheritance Law (2006)

2. R.I. Vinogradova, G.K. Dmitrieva, V.S. Repin, Commentary on the Civil Code of the Russian Federation (2002)

3. V.V. Gushchin, Yu.A. Dmitriev, Inheritance law and process (2004)

4. K.B. Yaroshenko, Commentary to the third part of the Civil Code of the Russian Federation (2002)

5. Bull. Const. Co. Rus. Fed., No. 2 (2000) 
6. V.B. Panichkin, O.Yu. Borovik, US Inheritance Law (2006)

7. V.B. Panichkin, O.Yu. Borovik, US Inheritance Law (2006)

8. Y.V. Truntsevsky, I.I. Lukiny, A.V. Sumachev, A.V. Kopytova, MATEC Web of Conferences 170, 01067 (2018) DOI: 10.1051/matecconf/201817001067

9. A. Kopytova, MATEC Web of Conferences 106, 08056 (2017) DOI: 10.1051/matecconf/201710608056

10. M. Gravit, O. Zybina, A. Vaititckii, A. Kopytova, IOP Conf. Ser.: Ear. Env. Sci. 90 (1), 012103 (2017) DOI: 10.1088/1755-1315/90/1/012103

11. D. Izvin, V. Lez'Er, A. Kopytova, MATEC Web of Conferences 170, 01065 (2018) DOI: $10.1051 /$ matecconf $/ 201817001065$ 